\title{
An Inside View of Microcredit in Panama: The Financial Investment in MFIs
}

\author{
Anna Paola Micheli \\ University of Cassino and Southern Lazio, Cassino, Italy
}

\begin{abstract}
The idea of this survey on microfinance in Panama arises from the importance of this financial sector in Latin America, in particular this paper analyzes the system of microcredit and estimate, among other things, the financial needs of the institutions of microcredit as a potential target of international investment. The present paper aims to provide a cognitive framework on microcredit in Panama. It wants to demonstrate how this country can be an area in which international investors can operate considering that this form of credit can improve their yields especially in countries, such as Panama, characterized by high interest rates. Under the methodological point of view, the paper considers the financial variables of microcredit in Panama. In this way, it reaches the goal of the research to identify MFIs (micro finance institutions) as a potential target of investors.
\end{abstract}

Keywords: MFIs (micro finance institutions), microcredit, investor strategy, microfinance, financial sector development, interest rate

\section{Introduction}

Microfinance is a sector in which a key role is played by micro-credit, which delivers loans of small amounts to disadvantages that of their characteristics are unable to obtain loans through the traditional channels. In Latin America and the Caribbean, there has been, in recent years, the expansion of the range of the microfinance sector, implemented through the operations of MFIs (micro finance institutions) with their services failing to reach an increasing number of families. Building on the success experienced by these institutions, even the traditional suppliers of financial services, such as commercial banks, have begun to pay more attention to this new option for business. In light of this, considering the role of MFIs in Latin American and their financial needs, the research focused on the system of microcredit in Panama. In fact, the government has implemented a program to support people who can not obtain by financial institutions money to carry out economic activities, because of poverty. To implement this program, the government of Panama, through Banco de Desarrollo Agropecuniario, supports the productive activities of the primary sector implemented by the rural population. The support is in place through the implementation of preferential loans in respect of that part of the Panamanian population at an interest rate of $2 \%$, which is in addition a further $1.5 \%$, if the loan is turned in against small entrepreneurs enrolled in the register of small- and medium-sized enterprises. The study confirms that the rates charged on microcredit are higher than those charged on lending ordinary,

Anna Paola Micheli, Ph.D., research fellow in Corporate Finance, member of Corporate Finance Lab (FinLab), University of Cassino and Southern Lazio, Cassino, Italy.

Correspondence concerning this article should be addressed to Anna Paola Micheli, Sant' Angelo Road, Cassino, Italy. E-mail: annapaolamicheli@virgilio.it. 
probably because of the risk implicit of customers to be funded, to the high financial costs and for the need, in the generality of MFIs, and to compensate for the lack of funding sources at low cost, which are deposits. The paper, in the first part, analyzes the system of micro-credit, focusing on MFIs, then it moves on to identification of the target company to which international investors can direct their activity. In fact, it is believed that to make the strategy of investment in microcredit sector successful, it is necessary to verify that the expected losses on the exchange rate must be more than offset by expected gains on the differential rate. In this case, Panama has wide margins of operativity given that from 2013 to 2014 the average pay off exchange rate and interest rate on microcredit are equal to $26.95 \%$. The result is to be ascribed to a positive average effect of $0.05 \%$ generated by the exchange and for the remaining part, to an average effect of $26.90 \%$ determined by the rate differential. Moreover, the average interest rate for loans to micro-credit is much higher than the interest rate for ordinary lending, by an average of $6 \%$. Then, the second part, analyzes MFIs in terms of legal status, portfolio, and clients, up to determine those, until you get to determine those that present investment opportunities to an international investor.

\section{Literature Review}

In Latin America, the experience of microfinance is widely illustrated by Adams and Von Pischke (1992), González-Vega and Miller (1990), and Christen (2000). The sector has had in recent decades, an exponential growth. Micro-credit, in particular, has increased in terms of number and volume of loans and improvement of services offered by financial institutions, especially the micro ones, regulated or not, which have consolidated its activity in the market. Some researches pointed out that micro credits loans improve the family welfare in terms of employment prospects education and health (Garikipati, 2013; Khandker, 1998; Morduch \& Haley, 2002; Zaman, 2004).

Otero, Rock, and Saltzman (1998) defined microfinance as the provision of direct financial services to the poor and self-employed people with low incomes. According to Ledgerwood (1999), these financial services include savings, credit, and other services, such as insurance and payment services. Schreiner and Colombet (2001) qualified microfinance as an attempt to improve access to small deposits and small loans by poor households neglected by banks. Thus, microfinance involves the provision of financial services, such as savings, loans, and insurance to the poor and to people living both in urban and rural areas and unable to obtain such services from the formal financial sector. In the literature, the terms "microcredit" and "microfinance" are often used interchangeably. It is appropriate, therefore, to highlight the differences in order to understand the dynamics. Sinha (1998) stated that microcredit refers to small loans, while the micro finance occurs when NGOs (non-governmental organizations) and MFIs alongside loan to other financial services side (savings, insurance, etc.). The micro finance plays a very important role in the development. Several studies have shown that microfinance plays three key roles in the development in particular, which are: (1) to help very poor families to meet basic needs and protect against risks; (2) to be associated with improvements in economic well-being of families; and (3) to support the economic participation of women and promote gender equity (Retrieved from http://www.uncdf.org/english/microfinance/). Many empirical evidences focused on the importance of the development of the financial system as a whole, however, especially in developing countries, the financial system does not meet the needs of all customers. The study on the financial system as a cause of growth is found in the works of Rajan and Zingales (1998); Beck, Demirgüç-Kunt, and Maksimovic (2005); and Levine, Loayza, and Beck (2000). Then, there is also a link between the financial system and poverty (Beck, Demirgüç-Kunt, \& 
Levine, 2004). Clarke, $\mathrm{Xu}$, and $\mathrm{Zou}$ (2002) found that a developed financial system helps to reduce income inequality. In contemporaneous studies, it emerges that MFIs have a key role on the long-term growth of the countries (Mundaca, 2009; Giuliano \& Arranz, 2005). Krauss and Walter (2008) affirmed that MFIs may have useful diversification value for international portfolio investors away from country risk exposures. For emerging market domestic investors, who may have this ability to a much more limited extent, domestic microfinance investments do not seem to provide significant portfolio diversification advantages. Lapenu and Zeller (2001) found that Asia accounted for the majority of MFIs, retained the highest volume of savings and credit, and served more members than any other. An increased attention is paid to investment funds (Janda \& Svárovská, 2010) and private investors' activities in MFIs (Srnec \& Gutierrez, 2010). This could create an opportunity for the development of microfinance.

\section{Analysis on Microcredit System}

In legal terms, the analysis on the system of microcredit of Panama shows the rules governing the financial system. It is contained in Law No. 9/1998 (Banking Law) as amended by Decree Law 2/2008. This law dictates the rules of banking as a whole. The Superintendencia de Bancos, an autonomous institution with its own administrative and financial independence, is called to ensure the smooth running of such activities. It has exclusive jurisdiction to regulate and supervise banks and banking as well as all other entities and activities that are assigned by other laws. The authorizations of intermediation are divided into three categories: (1) general licenses to conduct banking activities in Panama or abroad (both domestic and offshore) - banks operating with general license must have a paid-up capital of at least US\$ 10 million; (2) international licenses to conduct banking activities exclusively abroad — banks operating with international license must have a paid-up capital of at least US\$ 3 million, of which US\$250,000 deposited with the Central Bank of Panama; and (3) licensing representation for banks organized on the basis of foreign law, who have only the representation in Panama.

It is possible to distinguish Panamanian territory:

- two state-owned banks;

- thirty banks operating with the general license;

- thirty banks operating with international license;

- six MFIs.

In accordance with Article 79 of the Banking Law, banks can freely set the interest rate to be applied. Among all banks operating in the area, only a small number combine their ordinary activities with the microcredit or with the granting of loans to small- and medium-sized enterprises. They are referred in particular to: Banco de la Vivienda Panameño (grants loans to the agricultural sector, functional purchase of livestock), Capital Bank (grants loans to small- and medium-sized enterprises), Tower Bank International (grants loans to small- and medium-sized enterprises), Banco Agricola (grants loans to small- and medium-sized enterprises), Banco de la Nacion Argentina (finance micro-entrepreneurs), Bancolombia (financing small and medium enterprises), Banco Colpatria-Red Multibanca Colpatria (does microcredit), and GTC Bank (provides agricultural credit). Based on Superintendencia de Bancos de Panama data, it proceeded to acquire information on the liquidity and deposits within the banking system. According to Table 1, in particular, comparing the figures is possible to note that during 2012 to 2013, liquidity has increased, although at a lower rate than that recorded in 2012. In fact, the 
growth rate of liquidity in 2012 was $14.1 \%$ and therefore it was higher than four points compared to the rate recorded in 2013, accounting for 10\%. Deposits were down in the growth rate, which rose from $13.3 \%$ in 2012 to $12.8 \%$ in 2013 , but that decline appeared more limited than that of liquidity.

Table 1

Deposits and Liquidity From 2012 to 2013

\begin{tabular}{lllll}
\hline & \multicolumn{3}{c}{ Million (Balboa) } & Growth rate (\%) \\
\cline { 2 - 5 } & 2012 & 2013 & 2012 & 2013 \\
\hline Deposits & $14,905.21$ & $16,369.57$ & 13.3 & 12.8 \\
Liquidity & $15,787.31$ & $17,366.13$ & 14.1 & 10.0 \\
\hline
\end{tabular}

Source: Author's elaboration on Superintendencia de Bancos de Panama data.

Generally, in the assessment of the financial system of a country, it is customary to resort to the use of three factors represented by access, use, and quality of financial services. These factors, in fact, seem to be closely related to the degree of development of the financial system of each country. According to the report, Global Findex Database (World Bank) focused on the financial system in 2012. According to Table 2, it shows that $50 \%$ of the world's adult populations have an account at a financial institution: Forty-seven percent are women and $37 \%$ relate to the portion of the population between 15 and 24 years. With specific reference to Latin America on the basis of this report, it shows that $39 \%$ of adults have an account at a financial institution. It accounted for $35 \%$ of women and $26 \%$ of people between 15 and 24 years. Furthermore, $8 \%$ of the adult populations have contracted a loan in 2011. More than 250 million adults in the Latin American are excluded from access to credit.

Detailing further analysis and with reference to Panama, it is observed that $25 \%$ of the adult population have a bank account, in which $23 \%$ are women and $15 \%$ people between 15 and 24 years.

Table 2

Adult Population With Bank Account

\begin{tabular}{llll}
\hline Country & Adult population (\%) & Women (\%) & Population between 15 and 24 years (\%) \\
\hline World & 50 & 47 & 37 \\
Latin America & 39 & 35 & 26 \\
Panama & 25 & 23 & 15 \\
\hline
\end{tabular}

Source: Author's elaboration on World Bank data.

\section{MFIs}

The system of microfinance is regulated by Law No. 10 of 30 January 2002. This law aims to promote, strengthen, and develop the field of microfinance through the promotion of financial and credit services for people living in rural and urban areas. The law allows the organization and functioning of Banks of Microfinance (BMF), considered as financial institutions that have as main objective the lending to small and micro borrowers, which are located in urban and rural areas. These banks operate under the supervision of the Superintendencia de Boncos, in accordance with the provisions of Decree Law No. 9 of 1998, which regulates the conduct of banking business. Since 2005, a website has been set up dedicated to microfinance, called Red Pamif (Red Panameña de Microfinanzas). It is a NGO composed of 11 institutions which held a total portfolio of about 193 million dollars, on June 30, 2014, of which 7.9\% related to the rural sector. These institutions are represented by: (1) Banco Delta 
SA; (2) Banco G \& T Continental Panama; (3) Centro de Gestión Local para el Desarrollo Sostenible (CEGEL); (4) Centro de Estudio, Promocion y Asistencia Social (Cepas); (5) Financiero Empresarial Centre (CFE); (6) Cooperativa Juan Pablo I, RL; (7) Credit Financia; (8) Cooperative Juan XXIII, RL (Juan XXIII, RL); (9) I Tour; (10) Soluciones Microfinancieras SA (Microserfin); and (11) Asociación para el Desarrollo de las Cajas Rurales (Procaja).

Apart from the license needed to establish the BMF, there is no specific regulation on transparency. According to Figures 1 and 2, among these institutions, the main is represented by Banco Delta in terms of the portfolio, since it holds $70.71 \%$ of the total portfolio, both in terms of customers with $49.64 \%$ (data updated to June 2014). It follows Banco $G \& T$ Continental in importance in terms of portfolio.

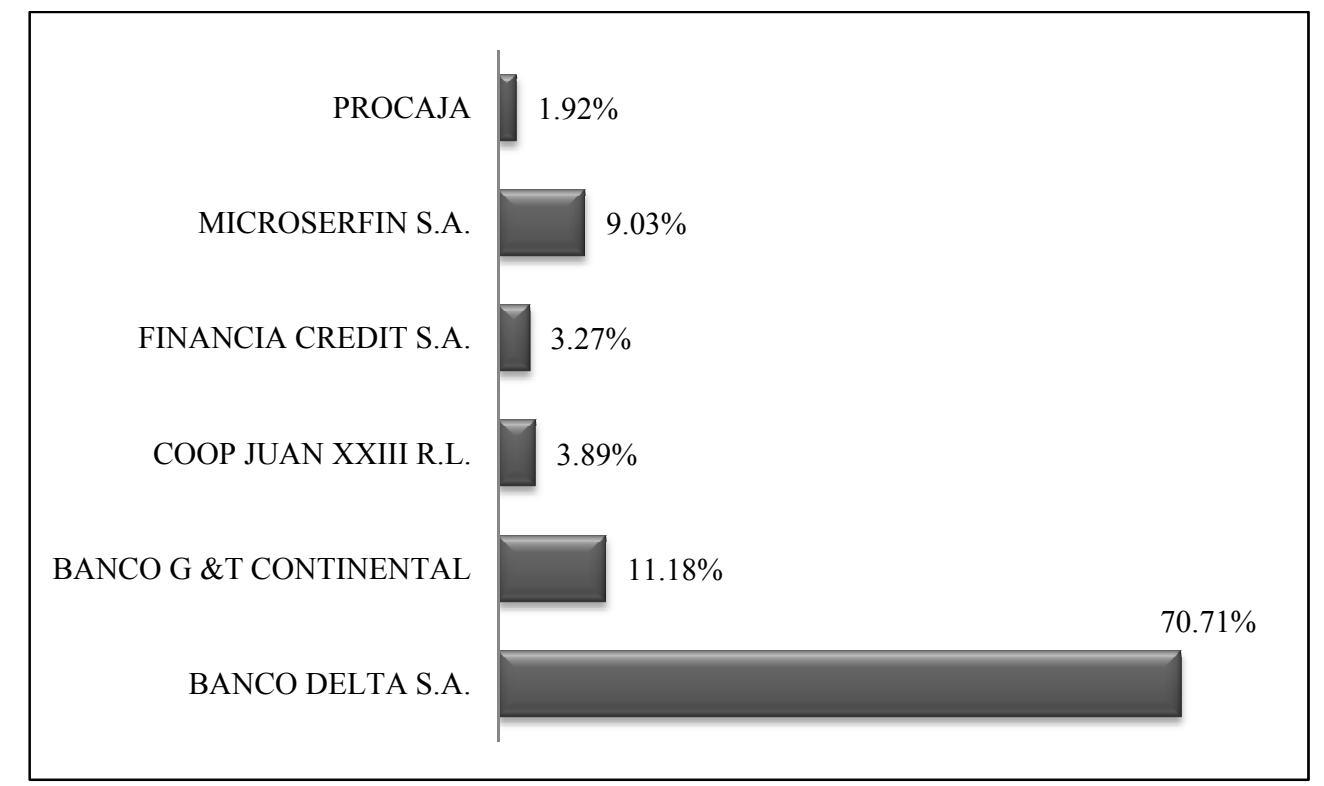

Figure 1. Loans (\%) for BMF. Source: Author's elaboration on Redcamif data.

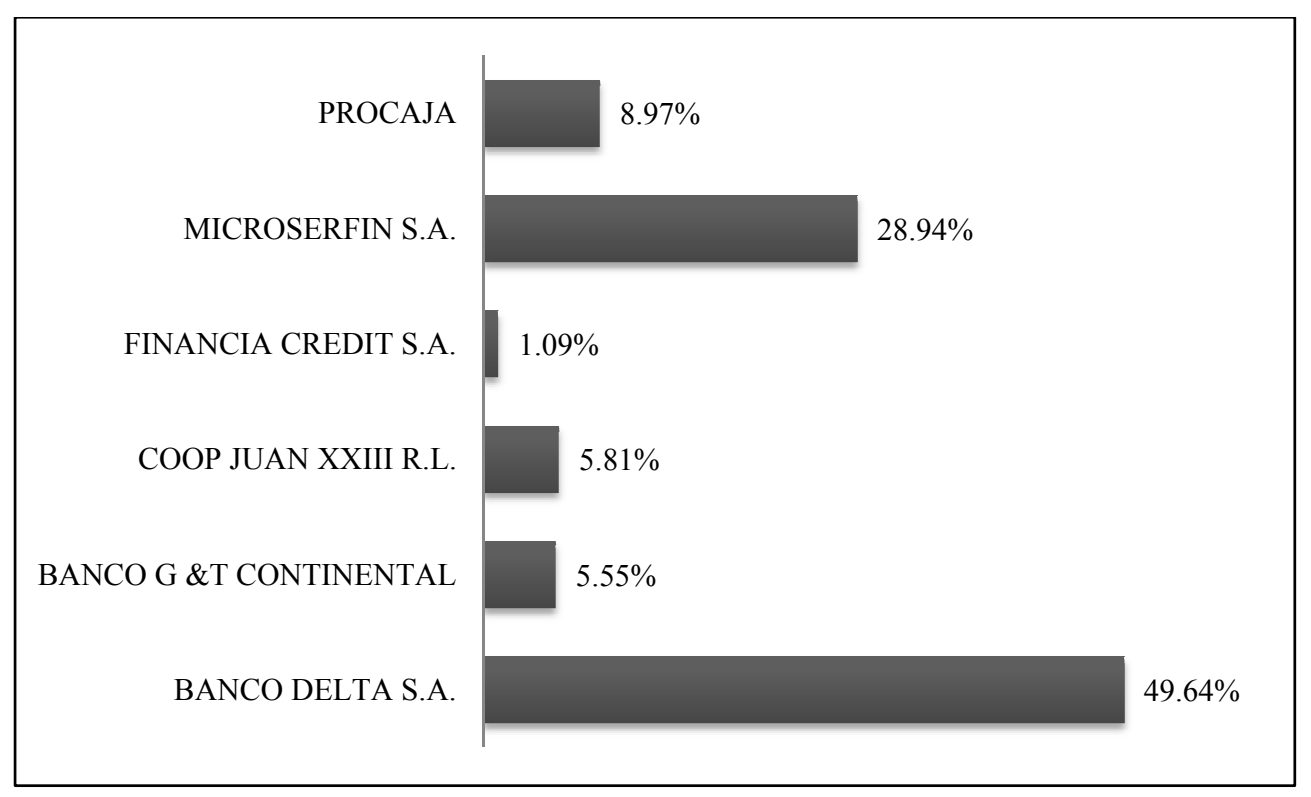

Figure 2. Costumers (\%) for BMF. Source: Author's elaboration on Redcamif data. 
In terms of clients immediately after Banco Delta ranks Microserfin that collects $28.94 \%$ of customers. In general, customers are mainly women. The loans are directed mainly to the sectors of trade, services, and consumer loans and most of them are longer than 24 months. On June 30, 2014, 100\% of the loans were granted in the form of individual loans.

MFIs can be classified into regulated and unregulated, depending on the fact that the institutions are subjected to the supervision of the Superintendencia de Bancos de Panama. Among the institutions under the supervision, there are some exercising microfinance activities organizing themselves in the form of banks and others that are categorized as Non Bank Financial Institution. The MFIs unregulated basically consist of NGOs.

The market of microcredit in Latin America is divided as follows in Table 3.

Table 3

Microcredit Portfolio and Clients in Latin America and Carribbean

\begin{tabular}{llllllll}
\hline Institutions & $N$. & $\%$ & $\begin{array}{l}\text { Microcredit portfolio } \\
\text { (million USD) }\end{array}$ & $\%$ & $\begin{array}{l}\text { Microcredit clients } \\
(N .)\end{array}$ & $\begin{array}{l}\text { Average } \\
\text { (USD) }\end{array}$ \\
\hline Regulated & 350 & 33 & 31,472 & 79 & $14,279,435$ & 65 & 2,223 \\
Banks & 174 & 16 & 24,861 & 62 & $9,648,913$ & 44 & 2,577 \\
NBFI & 135 & 13 & 6,581 & 16 & $4,548,572$ & 21 & 1,447 \\
Cooperative & 41 & 4 & 300 & 1 & 81,950 & 0.4 & 3,663 \\
Non regulated & 711 & 67 & 8,291 & 21 & $7,800,229$ & 35 & 1,063 \\
NGO \& others & 422 & 40 & 5,665 & 14 & $7,017,205$ & 32 & 807 \\
Cooperative & 289 & 27 & 2626 & 7 & 783,024 & 4 & 3,353 \\
Total & 1,061 & 100 & 40,033 & 100 & $22,079,664$ & 100 & 1,813 \\
Panama & 7 & & $135,122,104$ & & 32,953 & 72 & 8,545 \\
Regulated & 2 & 29 & $96,850,704$ & 28 & 17,810 & 46 & $6,395.74$ \\
Non regulated & 5 & 71 & $38,271,400$ & & & 54 & $2,148.87$ \\
\hline
\end{tabular}

Source: Author's elaboration on FOMIN data.

It shows a prevalence of unregulated institutions. The major part of the portfolio of microcredit is managed by the institutions regulated. The latter, although they represent $33 \%$ of the total of the institutions active in the field of micro-credit, manage the $79 \%$ of the total portfolio.

According to Table 4, microcredit represents $0.16 \%$ of the GDP of Latin America and $0.32 \%$ of the GDP of Panama. In addition, it constitutes the $1.82 \%$ of total loans granted by financial institutions, both regulated and unregulated $(0.36 \%$ for Panama), in which per 100 inhabitants active, about eight are clients of the microcredit sector (two with reference to Panama). In addition, using the analysis of the number of micro-entrepreneurs in the area of Latin America, there is the presence of about 25 microcredit clients every 100 micro-entrepreneurs.

Table 4

Microcredit Market in Latin America and Carribbean

\begin{tabular}{lllll}
\hline Country & $\begin{array}{l}\text { Microcredit/ } \\
\text { GDP }\end{array}$ & $\begin{array}{l}\text { Microcredit/ } \\
\text { Tot. credits }\end{array}$ & $\begin{array}{l}\text { N. microcredit clients/working } \\
\text { population }\end{array}$ & $\begin{array}{l}\text { N. microcredit clients/ } \\
\text { micro-entrepreneurs }\end{array}$ \\
\hline Panama & 0.32 & 0.36 & 1.82 & 7.21 \\
Latin America & 0.16 & 1.82 & 7.66 & 25.47 \\
\hline
\end{tabular}

Source: Author's elaboration on FOMIN data. 
According to Table 5, with reference to Panama, it emerges that within regulated financial institutions, most of credit is granted in the form of loans and trade loans. The portfolio of microcredit is a small percentage, only $5.72 \%$. The average interest rate practiced by microfinance institutions estimated in this study is approximately $26 \%$.

To identify MFIs' target to which an international investor can direct their activity, it proceeded with an interquartile division based on the size of their portfolio as shown in Table 6.

Table 5

Regulated Financial Institution

\begin{tabular}{|c|c|c|c|c|c|c|c|}
\hline Country & $\begin{array}{l}\% \\
\text { Loans to } \\
\text { business }\end{array}$ & $\begin{array}{l}\% \\
\text { Mortage } \\
\text { portfolio }\end{array}$ & $\begin{array}{l}\% \\
\text { Clients } \\
\text { mortgage } \\
\text { portfolio } \\
\end{array}$ & $\begin{array}{l}\% \\
\text { Consumer } \\
\text { loans portfolio }\end{array}$ & $\begin{array}{l}\% \\
\text { Clients } \\
\text { consumer loans } \\
\text { portfolio } \\
\end{array}$ & $\begin{array}{l}\% \\
\text { Microcredit } \\
\text { portfolio }\end{array}$ & $\begin{array}{l}\% \\
\text { Clients } \\
\text { microcredit } \\
\text { portfolio }\end{array}$ \\
\hline Panama & 27.83 & 27.07 & ND & 19.19 & ND & 5.72 & ND \\
\hline
\end{tabular}

Source: Author's elaboration on FOMIN data.

Table 6

Interquartile Division for Portfolio

\begin{tabular}{ll}
\hline Loans (USD) & MFIs \\
\hline From 0 to $6,259,871.75$ & Procaja \\
\hline From $6,259,871.75$ to $110,409,593.8$ & Financia Credit \\
\hline From $110,409,593.8$ to $309,156,662$ & $\begin{array}{l}\text { Cooperativa Juan XXIII } \\
\text { Microserfin }\end{array}$ \\
\hline
\end{tabular}

For each MFI, data of the assets were identified in outstanding loans, deposits, and equity. The acquisition of such values allows calculating a margin and an index, explaining the residual financing needs, such as the presumptive potential operation of an international investor. In particular, the formulas are the followings:

$$
\begin{aligned}
& \text { Net Requirement of the Loans Portfolio }=\text { Credits }- \text { Deposits }- \text { Equity } \\
& \text { Net Requirement Ratio }=(\text { Loans }- \text { Deposits }- \text { Equity }) / \text { Loans }
\end{aligned}
$$

Both indicators (Tables 7 and 8) explain how much portion of loans granted remains uncovered.

Table 7

MFIs Indicators (1)

\begin{tabular}{lllll}
\hline MFIs & Active & Loans portfolio & Deposits & Equity \\
\hline Banco Delta, S.A. & $195,232,503$ & $131,180,831$ & $125,867,859$ & $24,837,736$ \\
Coop Juan XXIII & $13,005,918$ & $7,507,028$ & $6,572,565$ & $4,785,398$ \\
Credi Factor Panama & $341,369,812$ & $309,156,662$ & n.d. & $54,433,994$ \\
Financia Credit & $7,773,273$ & $5,844,153$ & 0 & $2,651,307$ \\
Microserfin & $16,198,479$ & $16,434,299$ & 0 & $5,291,572$ \\
Procaja & $3,747,500$ & $3,234,662$ & 260,707 & $1,093,634$ \\
\hline
\end{tabular}

It should be noted that Financia Credit, Microserfin, and Procaja, which have a value of positive, could represent a potential target for international investor. 
Table 8

MFIs Indicators (2)

\begin{tabular}{lll}
\hline MFIs & Net requirement of loans portfolio & $\begin{array}{l}\text { Net requirement } \\
\text { ratio (\%) }\end{array}$ \\
\hline Banco Delta, S.A. & $-30,690,757$ & $-14.88 \%$ \\
Coop Juan XXIII & $-3,850,935$ & $-51.30 \%$ \\
Credi Factor Panama & n.d. & n.d. \\
Financia Credit & $3,192,846$ & $54.63 \%$ \\
Microserfin & $11,142,727$ & $67.80 \%$ \\
Procaja & $1,880,321$ & $58.13 \%$ \\
\hline
\end{tabular}

\section{Conclusions}

After analyzing the microcredit of Panama, the paper concludes that this country has the condition for international investors who want to operate in the field of microfinance. The paper shows that considering the high interest rates on microcredit and the pay off between exchange rate and interest rate on microcredit, Panama can ensure good margins of profit to investors. Among seven MFIs analyzed, the research identifies three institutions as potential target of international investor considering the ratios used in the research. In fact, only those MFIs with net requirement of loans portfolio and net requirement ratio positive could be selected for the supposed investor.

\section{References}

Adams, D., \& Von Pischke, J. D. (1992). Microenterprise credit programs: 'déjà vu. World Development, 20, 1463-1470.

Beck, T., Demirgüç-Kunt, A., \& Levine, R. (2004). Finance, inequality, and poverty: Cross-country evidence (NBER Working Paper No. 10979).

Beck, T., Demirgüç-Kunt, A., \& Maksimovic, V. (2005). Financial and legal constraints to firm growth: Does firm size matter? Journal of Finance, 60, 137-177.

Christen, R. P. (2000). Review and outlook. In G. D. Westley and B. Branch (Eds.), Development of credit unions effective in Latin America. Washington, DC: Inter-American Bank and World Council of Credit Unions.

Clarke, G., Xu, L. C., \& Zou, H. (2002). Finance and income inequality: Test of alternative theories. Annals of Economics and Finance, Society for AEF, 14(2), 493-510.

Garikipati, S. (2013). Microcredit and women's empowerment: Have we been looking at the wrong indicators? Oxford Development Studies, 41(1), 53-75.

Giuliano, P., \& Arranz, M. R. (2005). Remittances, financial development, and growth (IMF Working paper 5/234, International Monetary Fund).

González-Vega, C., \& Miller, T. (1990). Theoretical framework and experiences in financing small business in financing and support to small enterprises. San José: Academia de Centroamérica.

Janda, K., \& Svárovská, B. (2010). Investing into microfinance. Journal of Business Economics and Management, 11, 483-510.

Khandker, S. (1998). Fighting poverty with microcredit: Experience in Bangladesh. New York: Oxford University Press.

Krauss, N., \& Walter, W. (2009). Can microfinance reduce portfolio volatility? Economic Development and Cultural Change, 58(1), 85-110.

Lapenu, C., \& Zeller, M. (2001). Distribution, growth and performance of microfinance institutions in Africa, Asia, and Latin America (Food Consumption and Nutrition Division Discussion Paper No. 114, International Food Policy Research Institute).

Ledgerwood, J. (1999). Sustainable banking with the poor: Microfinance handbook-An institutional and financial perspective. London: Pinter.

Levine, R., Loayza, N., \& Beck, T. (2000). Financial intermediation and growth: Causality and causes. Journal of Monetary Economics, 46, 31-77. 
Morduch, J., \& Haley, B. (2002). Analysis of the effects of microcredit on poverty reduction (New York University Wagner Working Paper No. 1014). Hull: Canadian International Development Agency.

Mundaca, B. G. (2009). Remittances, financial market development, and economic growth: The case of Latin America and the Caribbean. Review of Development Economics, 13(2), 288-303.

Otero, M., Rock, R., \& Saltzman, S. (1998). Principles and practices of microfinance governance. Retrieved from http://www.gdrc.org/icm/govern/govern.pdf

Rajan, R., \& Zingales, L. (1998). Financial development and growth. The American Economic Review, 88, 559-586.

Schreiner, M., \& Colombet, H. H. (2001). From urban to rural: Lessons for microfinance from Argentina. Development Policy Review, 19, 339-354.

Sinha, S. (1998). Microcredit: Introduction and review. IDS Bulletin, 29(4), 1-9.

Srnec, K., \& Gutierrez, R. E. (2010). The scenario of microfinance in Latin America against the international financial crisis. Agricultural Economics-Czech, 56, 583-590.

UN Capital Development Fund [UNCDF]. (2004). UNCDF microfinance. Retrieved from http://www.uncdf.org/english/microfinance/

Zaman, H. (2004). The scaling-up of microfinance in Bangladesh: Determinants, impacts and lessons (World Bank Policy Research Working Paper No. 3398). Washington, DC: World Bank. 